\title{
Moving beyond fan typologies: \\ The impact of social integration on team loyalty in football.
}

\author{
Contact author: \\ Dr Ian Fillis \\ Stirling Management School \\ University of Stirling \\ Stirling FK9 4LA \\ Scotland \\ Email: i.r.fillis@stir.ac.uk \\ Tel: 01786467392 \\ Fax: 01786464745 \\ Craig Mackay \\ Stirling Management School \\ University of Stirling \\ Stirling FK9 4LA \\ Scotland \\ Email: craigmackay5@hotmail.com
}

\section{Author biographies:}

Ian Fillis' research interests include small business marketing, creativity, arts marketing, research methodology, international and export marketing, e-business and aesthetics. He has published widely in outlets such as the International Small Business Journal, Journal of Marketing Management and the European Journal of Marketing, as well as research monographs and book chapters. He has carried out a number of funded projects, including several concerning the socio-economic impact of the crafts sector. He is previous Chair of the Academy of Marketing Entrepreneurial and Small Business Marketing Special Interest Group. He has also served as Guest Editor on a number of special journal issues concerning small business and has delivered invited seminars on creativity, research methodology, small business and arts marketing to universities in the UK, Sweden, Finland, Australia and the USA.

Craig Mackay is a marketing graduate of the University of Stirling, and has a keen interest in football and sports marketing. He currently works as a Market Research Specialist for Sercon Support Services in the cleaning and security markets, carrying out a range of research projects, as well as strategy and planning activities. 


\title{
Moving beyond fan typologies: The impact of social integration on team loyalty in football.
}

\begin{abstract}
The purpose of this paper is to develop detailed insight into loyalty among football fans of Hibernian FC, moving beyond typologies to a more socially grounded approach. Issues explored included patterns of consumption, distinctions between fan groups and antecedents of loyalty. The origins and development of the club are evaluated and consumer fanaticism, football fan loyalty, consumption behaviour and the sociological impact of fan communities are discussed. Data is collected using a variety of methods, including participant observation, in-depth interviews and analysis of websites and fan forums. Key findings relate to the impact of family and community influences on loyalty, initial experiences of developing associations with the club, through to the impact of socialisation and the lived experience of being a supporter. A supporter matrix is constructed as an portrayal of the loyalty found at the club. A range of theoretical implications are considered, and the matrix promoted as a tool for understanding loyalty in clubs with similar social structures and community connections.
\end{abstract}

The originality of the paper lies in its ability to move beyond dichotomous and tiered approaches to understanding, as well as making contributions to theory by embedding the research socially.

Key words: loyalty, football, consumption, fanaticism, case study

\section{Introduction:}

The main research objective of this paper centres on reaching an improved understanding of football loyalty by assessing the impact of social integration, rather than just focusing on the application of existing fan typologies to explain the relationship. This leads to the related objective of improving understanding of how fans exhibit various patterns of football consumption. In order to achieve this, the antecedents of this contemporary loyalty must be understood, together with the sociological influence of community. This is achieved through case study analysis of a Scottish football club and the relationship with its supporters. In order to assess the impact of social integration on team loyalty in football, this paper is structured as follows. A case study analysis of Hibernian Football Club, currently in the Scottish Premier League is developed. Its origins as a club founded as the result of the social needs of the local immigrant Irish community are discussed. An assessment of the 
supporter/club relationship is then developed, with attention paid to research on consumer fanaticism, sports and football fan loyalty and their consumption behaviours. The social aspect of the relationship between club and supporters is assessed using the concept of fan communities, while religiosity and sacred consumption explain how devoted consumers develop in-depth relationships with their place of worship. In order to conceptualise how fans with differing levels of involvement interact with the club, an evaluation of fan typologies is carried out. The researchers use a fan community spectrum as the research instrument in measuring supporters' level of loyalty. By triangulating a variety of data sources, an understanding of the influences on loyalty is reached, including those which are socially constructed.

An adjusted framework termed the supporter matrix is then used as a more appropriate mechanism for understanding the loyalty associated with the club. Although the research is specific to one club, the findings have implications for other clubs with a strong sense of community. Sport in general has progressed to a point where it is now managed and marketed, rather than administered (Shilbury et al. 2003) and where understanding its consumers leads to enhanced loyalty and club profitability (Ferrand and Pages 1996; Beech and Chadwick 2007). All seater stadia in the higher level leagues in England, Scotland and elsewhere have also impacted on how fans consume and interact with one another (King 1997). Sports consumers can be segmented demographically, culturally and socially and the lifetime value of a highly loyal fan is likely to be much greater than that of an occasional supporter (Tapp and Clowes 2002). A spectator may only have a brief memory of the event after the experience but fans continue to hold interest to such an extent that it becomes part of their everyday consumption practices (Pooley 1978). Sports marketers endeavour to shape the 
relationship between club and fan but the social shaping of loyalty empowers the fan to exert increasing influence on the relationship.

\section{Origins and development of the club:}

The relationship between Scottish football and its supporters has been described as an obsession which impacts on local, national and global identity (Mason 1989). Football develops sporting prowess and conveys social, cultural and political identities (Burdsey and Chappell 2001). To understand the relationship between the club, its supporters and the wider community, its origins and development are considered. In the nineteenth century large numbers of Irish economic immigrants moved to Scotland, shaping the cultural and ethnic identity of their Scottish born descendants (Bradley 1998). This identity is partly expressed through football support. Scottish football club development was influenced by the indigenous Scots and the migrant Irish communities, leading to expressions of social identity. Together with Celtic FC, Hibernian FC has a long connection with Irish heritage (Kelly 2007). In order to deal with religious, moral and social issues, the Edinburgh Hibernians were formed in 1875 (Mackay 1986; Lugton 1995). This gave the Catholic community, and in particular the Church's Catholic Young Men's Society, a focus as well as a healthy pastime. In the club's early years, Hibernian FC players had to be practicing Catholics. This religious impact has lessened, although there is still evidence of particular allegiances begin expressed by supporters, depending on the opposition team. The Hibernian Historical Trust (www.hibshistoricaltrust.org.uk) was established by the club and its supporters to promote, preserve and protect the club heritage. The popularity of Hibernian FC at local community level and beyond can be clearly seen (Wright 2010; MacVannan 2011). In the current Scottish League format, twelve teams compete at the top level, although no team outside of the Old Firm (Rangers and Celtic) have won the contest. The poor financial state of many 
Scottish football clubs has affected their development (Morrow 2004; 2006). This compares with the bigger picture where the total European football market in 2009/2010 was $£ 13$ billion, despite the economic downturn (Deloitte 2009), growing to £13.7billion in 2010/2011. In 2010/2011, Scottish club turnover was £171million. The revenue generated by Hibernian FC fell eight per cent from $£ 7.7 \mathrm{~m}$ to $£ 7.1 \mathrm{~m}$ in 2010 .

In order to understand the impact of social integration, the literature review adopts the following structure. Firstly consumer fanaticism in general is evaluated, before focusing on sports fan loyalty. Different forms of loyalty in football are then evaluated, from flaneurs to fan resistance and the role of cultural capital. Fan communities, love of place or topophilia and other community influences are then discussed. Finally, a range of existing frameworks are assessed which identify different fan types shaped by loyalty and other social influences.

\section{Consumer Fanaticism:}

Social integration is shaped by consumption as a type of social action where people make use of consumption objects in different ways (Holt 1995). There is a growing body of empirical work on fans as consumers, although there is still a need for further work to clarify the effects of social integration on fan loyalty and the fan consumption process. This research can build on earlier contributions such as Holt (1995) and Richardson and Turley (2006) in highlighting the importance of group dynamics on this process. Fans as consumers coproduce through their consumption practices, exhibited in a variety of ways by different fan groups. They enhance their experience through elevated levels of involvement, even though they might not necessarily recognise this (Decrop and Debraix 2010). Reasons for consuming include the desire to seek out the experience and obtain and manipulate object meanings through ritualisation behaviours. With consumption as play, fans engage in order to share 
their experiences through communing with others. With consuming as experience, shared experiences among a group of loyal fans can be enjoyed. The emotion associated with fanaticism is shaped by fan behaviour ranging from obsessive, compulsive dysfunctional activities to less excessive displays. A fan is an individual with a lasting connection with a particular subject, while fanaticism is the level of intensity concerned (Thorne and Bruner 2006). Fandom involves a subculture of a group of like minded people with common interests. Fans exhibit higher level internal involvement than non fans and are prepared to alter their lifestyles to accommodate their fanaticism (Redden and Steiner 2000; Thorne and Bruner 2006). External involvement activities such as searching for team statistics, reading about team performance and actual match attendance are also key indicators of fan behaviour. Fans express a desire for social integration with like minded people and often acquire memorabilia such as match programmes and fanzines.

\section{Loyalty of football consumers:}

The terms 'fan' and 'supporter' tend to be used interchangeably, with little attention paid to identifying any differences (Crawford 2003). Researchers have categorised the level of interest or attachment of sports fans with their club and the sport. Fans, above all other stakeholders in a club's network, play a leading role in creating value, achieved through their ability to influence its social aspects (Zagnoli and Radicchi 2010).. The connection between fans and their team has been termed allegiance (Funk and James 2006), commitment (Mahoney et al. 2000), loyalty (Tapp 2004) and pride (Decrop and Derbaix, 2010).

Conceptualisation of football consumption already exists but understanding the impact of social integration on moving between loyalty categories needs to be extended (Tapp 2004; Taylor 2004). Football is now consumed in a variety of ways beyond traditional match 
attendance where fans may not be any less loyal, even though they do not physically attend a game. Motivation shapes match attendance, club allegiance, and the development of loyalty (Funk and Brunn 2007; McDonald et al. 2010). Physical attendance and viewing the game on television or via the internet are all forms of sports consumption and measures of behavioural loyalty (Wann et al. 2001; Bauer et al. 2008). Since loyalty involves an attitude behaviour relationship, this enables the investigation of antecedents that either strengthen or loosen the connection (Dick and Basu 1994). Factors which shape fan attendance relate to their desire for experiential benefits such as group affiliation, camaraderie, entertainment and self esteem enhancement (James and Ross 2004; Pritchard et al. 2009). These then raise the level of involvement surrounding the activity (Funk et al. 2004). Attendance can evoke similar feelings to those at a political rally or a religious gathering (Pritchard and Funk 2010).

\section{The flaneur, fan resistance and cultural capital:}

Commodification is the process by which an object or social practice acquires an exchange value or market-centred meaning (Giulianotti 2002). Sports consumers make choices in order to obtain the best return for their investment in time and money. The conventional argument is that if the club fails to deliver the expected benefits of support, the customer will look elsewhere for satisfaction (Critcher 1979). Traditional fans, however, view themselves as members of the club and are unlikely to transfer their allegiance. Giulianotti's taxonomy of football spectator identities includes supporters, followers, fans and flaneurs (Giulianotti 1999; Walsh and Giulianotti 2001). Each category can be evaluated against hot-cool and traditional-consumer binary opposites. Traditional spectators exhibit longer term, local connections while consumer fans are more market oriented. The hot-cool dimension relates to earlier research on mass media communication (McLuhan 1964; Baudrillard 1990). Casual, unattached spectators have been viewed as flaneurs, strollers or unreconstructed, cool consumers who have no specific association with a particular club but who desire to be seen 
at important events. They exhibit little evidence of social integration. Being a flaneur refers to a complete philosophical way of living, thinking and observing (Benjamin 1999). The growth of the wealthy football flaneur has impacted on the ability of the true, but financially poorer, supporter to follow the team through match attendance (Giulianotti 2002). The original working class masculine supporter is gradually being replaced by so called "genuine" middle class spectators with a claimed interest in family football, spectacle and skill (Taylor 1971; Dunning 1986).

Continuing this sociological perspective, King (1997) evaluates the Lads as a particular form of male football supporter. The masculine nature of pride expressed by the Lads relates to their perceived elevated status within the supporter community and involves competition for honour among other men (Tolson 1997). They share a self created sense of euphoric solidarity, expressed through songs and an unconditional love of the team. Research has adopted a hegemonic perspective on fan consumption; for example, the Birmingham School examined the role of ritual as a form of resistance (Hall and Jefferson 1976; Willis 1977; Fiske 1992). Analogies are made with Durkheim's (1964) study of clans coming together to worship their totem, with the Lads displaying similar euphoria for their team (Giulianotti 1994). Richardson and Turley (2006) investigate resistance, subculture and the desire for distinction amongst football supporters, using subcultural capital to explain how supporters assert their perceived superior status within the wider fan base. Cultural capital is the necessary knowledge needed to consume, appreciate and understand taste (Holt 1998), as well as how, rather than what, we consume (Muniz and O'Guinn 2001). The core inner level of support is a particular form of consumer resistance as fans react to outside interference from other club managers, fans and the media (Ritson and Dobscha 1999). Sets of fans within brand communities develop their own versions of cultural capital in order to make claims of 
superiority over other fan groups. Community specific expressions of this capital are also evident. The institutions associated with football help shape the assembly of these fans and their related subcultures as they actively distance themselves from the mainstream. Differences in economic and cultural capital create the sense of community within fan subculture, helped by a heightened level of communication and integration within it. Subcultural capital can be contextualised against the high levels of accessibility of mass culture, or the mainstream. Membership of the subculture is driven by a sense of exclusivity (Thornton 2002).

\section{Fan communities, topophilia and other related influences:}

For some, the club becomes an extension of the self in shaping identity while, for others, the level of engagement is not so important. Fan culture has been viewed as an imagined dynamic community as part of everyday life (Nash 2000; Crawford 2004). The wider social role of football should also be considered as part of everyday consumption experiences (Stone 2007), in addition to the collective emotional and practical behaviour of spectators such as shouting at the match officials, talking with those seated next to each other and watching the game (Giulianotti 2005). These interactions are termed Wechselwirkung by the sociologist Georg Simmel.

Group processes play a pivotal role in football consumption (Derbaix et al. 2002). Consumers make choices based on the social opportunities the brand offers and the value it creates (Muniz and O'Guinn 2001). Attraction to football occasions can be measured by adopting a socialisation perspective involving experiencing an event, acquiring knowledge, socialising and sharing the knowledge and experience with others in the community (Pons et al. 2006). A fan community is a form of social network containing interacting individuals in a town, city or wider domain (Bale 2000). In addition to national and global contexts, community at an 
urban level refers to where the club is located, who and what it represents and is usually named after it. It also relates to the smaller scale community in which it is sited i.e. the individuals and businesses in close proximity to the stadium.

The love of place, or topophilia, relates to the impact of football stadia on generating heightened psychological benefits for the community (Tuan 1974). Individuals form an emotional attachment to a place where feelings and bonds occur in a similar way to that between people (Gonzalez 2005). A football team is an icon and representation of the local area (Van Houtum and Van Dam 2002), while football helps shape and communicate local identity within the space (Bale 1988). The stadium is the home ground which needs to be defended by supporters in their imagined community against the opposition. Involvement in football facilitates a sense of integration, community and belonging which might be missing elsewhere in an individual's life.

Although the focus of this paper is on the community of supporters attached to a specific club, the notion of the fansumer (fan as consumer), often as part of a much larger fan nation with a physically distant supporter base, has some relevance (Gruneau and Whitson 1993; Euchner 1993; Foster and Hyatt 2008). Fansumers utilise social processes in order to form attachments with the club and other fansumers. However, the levels of commitment of the fansumer and flaneur are not as high as others in a club's imagined community (Euchner 1993; Giulianotti 2002). Further empirical work is needed to confirm this in case it represents a form of rhetoric deployed by some fans to further assert their sense of distinction over others.

The development of community attachments to a particular club is facilitated through social processes (Melnick 1993; Carbaugh 1996). A key factor underpinning the fan base is the sense of belonging, where the tribus as a form of neo-tribe concerns how individuals collect 
together and self organise because of their particular lifestyle (Crawford 2004). It contains a certain 'warmth' which is not available elsewhere. There are potential differences between neotribal fan communities and traditional fan subcultures. Often the subcultural fan references the consumer practices of those fans who may have more recently migrated towards the tribal spaces around clubs to assert their distinction. Fan affiliation can also be understood using the lifestyle enclave as a type of social gathering concentrated around patterns of consumption (Bella et al. 1996). This has parallels with a brand community, or a structured set of social relationships among admirers of a brand (Muniz and O'Guinn 2001). Overlaps include shared consciousness, rituals, myths, values, vocabulary, hierarchy and traditions (Cova 1997; Bagozzi 2000; Cova and Pace 2006). Brand communities and brand tribes have been used to evaluate the relationship between consumers and brands (Muniz and O'Guinn 2001; Arnould et al. 2002). Also, on-line brand communities are a form of consumer empowerment and communal consumption where groups construct a sub-culture surrounding a particular brand. Football fans utilise on-line fan forums, other websites and fanzines to develop their communities (Gruen et al. 2005).

The support displayed by core fans can be likened to the religiosity amongst certain consumers within a brand community (Muniz and Schau 2005). Drawing on their study of an apparently abandoned brand community, religious motifs can be identified in football supporter narratives. These narratives within brand communities can affect future behaviour. The football club as a brand fuels this religiosity which is shaped by both tangible and intangible consumption forces. Modernity, market capitalism and the brand also influence religiosity (Marchand 1985; Lasch 1991). In those communities which become, or seek to be marginalised, there is a sense of the underdog. Becoming further marginalised drives the demand for this particular subculture. Consumption as religiosity has been viewed as a 
sacred, rather than profane or ordinary, everyday form of consumption practice and experience which then shapes loyalty within public cathedrals (Belk et al. 1989). Football fans may undergo a 'conversion experience' as they develop loyalty through displays of reverence and worship of their team and its manager. The work of Durkheim and Eliade (Stirrat 1984) uncovers aspects particularly relevant to the fan including sacrifice, commitment, ritual, ecstasy, flow and communitas. This last factor is the social antistructure which enables individuals to move way from their everyday roles so that they can take part in collective transcendent behaviour. Sacred consumption occurs in specific places and times; for example around match day. The tangibilisation of the consumption includes the wearing of football shirts, waving flags and displaying other emblems. Match day experiences and the songs sung or chanted are examples of its intangible aspects.

The virtual fan community is an extension of the fan community based around the club, stadium, local area and the wider environment (Kozinets 1999). Here, football supporters can also communicate with each other through their e-tribes (Rheingold 1993). Fans as virtual consumers also exhibit sacred consumption as they gather together in collective worship and commentary of their team.

\section{Fan typologies:}

Not all fans are necessarily motivated by the same factors, although the preceding discussion has highlighted the importance of social integration for some. However, existing fan typologies largely fail to address this. Typologies and other classification systems identify common characteristics or traits. The dualistic typology compares and contrasts one behavioural form with an opposing one (Ferrand and Pages 1996; Clarke 1978; Boyle and Haynes 2000; Nash 2000; Quick 2000; Lewis 2001). This is a starting point in understanding 
team affiliation (Stewart et al. 2003) but there is also a need to evaluate the meanings which fans attach to their sport experiences in order to understand the role of social integration and other contributing factors (Bristow and Sebastian 2001).

With tiered models, fans are grouped and ranked according to their emotional or financial commitment (Clowes and Tapp 1999; Thorne and Bruner 2006). The inclusion of the emotional dimension contributes to explaining how and why social integration occurs (Berkman et al. 2000). In identifying five fan types, Hunt et al. (1999) believe that team performance is not the sole indicator of fan behaviour and that a fan can be a fan of the sport, the team, the league or a particular player. Although Hunt et al. (1999) focused on American sport, the approach does offer a reasonable foundation in suggesting that fans might follow a sequential path in their displays of loyalty. The Psychological Continuum Model (PCM) shows the different levels of a fan's relationship with a team (Kolbe and James 2000; Funk and James 2001). Evaluating the transition from attachment to loyalty is largely perceptual, concerning strengthening psychological attitudes and knowledge. Tiered models enable greater understanding of football consumption through their more detailed insight into the fan/team relationship but they are unable to easily differentiate difference within each level or to explain why fans might move between levels.

Multidimensional typologies include a range of complex social and psychological dimensions which impact on fan behaviour and help explain the need for social integration (Holt 1995; Mahoney et al. 2000). They account for the motives of consumption, as well as the meaning and loyalty contained in the relationship, including the amount of emotional attachment and attendance frequency (Wann and Branscombe 1993). This approach is more rounded since it includes geodemographic and psychographic dimensions, as well as a consideration of the benefits sought in the relationship. Allegiance with a team can be likened to a career, where 
people can occupy similar positions, yet display different characteristics (Crawford 2003). At the height of a career, the devoted and professional fan show natural understanding or knowledge.

The literature review has shown that football fans demonstrate their affinity with a club through a number of mechanisms. Existing fan typologies are a starting point in understanding their levels of loyalty but cultural, social, motivational and consumption based influences are also relevant. So the central research questions resulting from the analysis of the literature and understanding of the sector can now be presented: As set out earlier in the paper, the main research objective focuses on reaching an improved understanding of football loyalty by assessing the impact of social integration, rather than just focusing on the application of existing fan typologies to explain the relationship. In order to assess this further, these additional research questions are addressed: What are the key motivating factors relating to the loyalty of the fans of Hibernian F.C. which move them from being attracted to being attached? How can we reach an understanding of the mechanisms behind fan movement, in any direction, within any presented continuum or matrix? Is fan loyalty constructed differently across fan typologies? These central issues are addressed in the presentation, discussion and analysis of the research findings.

\section{Methodology:}

The research adopted a case study approach. A case study is an empirical inquiry that investigates a contemporary phenomenon in depth and within its real life context, especially when the boundaries between phenomenon and context are not clearly evident (Yin 2009). It is particularly useful in new and under-developed areas (Eisenhardt 1989), where current perspectives bring little new understanding and where existing theory is deemed inadequate or not relevant. Case study methodology permits several levels of analysis to be carried out. The data was triangulated in order to confirm the reliability of the findings (Denzin 1979) and 
assessed using thematic analysis (Taylor and Bogdan 1984; Boyatzis 1998). Approaches included secondary data analysis, in-depth interviews, participant observation and netnography (Kozinets 1999; Bryman 2008). Two researchers were involved, one with prior interest in the club and the other with no connection who carried out cross checking of the findings. Therefore the issue of distance was addressed and the making of the familiar strange was dealt with (Lofland and Lofland 1984). As qualitative research was mainly carried out, it is acknowledged that subjectivity impacted on the research process. Participant observation and in-depth, ethnographic interviewing are different and yet related, since the data collected from the former is often derived from informal interviewing in the field. The participant observation element utilised here begins to resemble an ethnographic study but the shorter time period involved resulted in it contributing to the case study approach. Ethnographic studies can be as short as a week but can last up to several years (Sands 2002). Ethnography is widely used to study group consumption (Holt 1995; Decrop and Debraix 2010).

Participant observation involved attending matches and becoming immersed in the match day experience. Ten games were attended over a four month period ( 6 home and 4 away). The process started with a general observation of the fan base but then narrowed with time spent with more specific fan groups. This enabled the researcher to become more accustomed to different match day rituals, meet with more contacts and to provide heightened context. The time spent collecting the data also contributed to the quality of information gathered. By also consulting online fan forums, this made it possible to monitor fan interaction. Adoption of this netnography approach resulted in higher level research question relevance (Kozinets 2001). The online forum was constantly monitored for relevant events, while also serving as a way of further immersion with the fan base. An interview was held with the Commercial and Communications Director of the club in order to reach an initial understanding of the 
relationship between the club and its fan base, and for background information. The information was cross checked for validity. A purposive sampling approach was appropriate in identifying interview respondents since the fans come from broad geographical and economic strata (Decrop and Debraix 2010). Sample construction was assisted by building up a network of informal contacts through attendance at games and interacting on an online fan forum, following King's (1997) study where observing fans in context and interviewing them added perspective and enhanced the scope of results. A strategy used in purposive sampling is the search for critical cases where individuals make a point dramatically (Paton 1980). It was important to find fans who exhibited different levels and forms of support. Consequently one of the researchers contacted leading organisations connected with the club's supporters in order to help locate these different fan types. The male dominance in the sample $(13: 3)$ is reflective of the actual support, with some being season ticket holders and/or members of supporter clubs. Supporter age ranged from twenty to mid sixties. Open ended questions posed to the fans were piloted and sixteen face to face interviews with supporters were completed, with all interviews being recorded and transcribed (Kent 2006). Research initially focused on assessing the fan segments in the supporter base and identifying their distinguishing characteristics. Evidence of a sequential pattern of support was also sought, as well as the main antecedents of loyalty and pride.

\section{The Fan Community Spectrum:}

Respondents were asked to indicate their level of loyalty on the Fan Community Spectrum constructed by the authors and drawn from the existing research on fan typologies and other indicators of behaviour as discussed in the literature review, together with a pre-existing understanding of the existing club/supporter relationship. (Figure 1). The spectrum adopts the following classifications. Situational fans feel that football and the club are not a big priority 
in life, with match attendance depending on time, money and location. They may attend specific games such as cup finals and European matches. The temporary and local fan categories were combined to construct this category. Kids are new young fans whose support is developing and who still lack understanding of the history and traditions of the club. Devoted fans display loyalty towards the club, characterised by regular attendance at games and wearing club colours. This fan most likely owns a season ticket and goes to home and some away matches. The $12^{\text {th }}$ Man is very vocal in support of the club and use of songs is particularly evident. They have characteristics of the devoted fan but, through their display of team colours and banners, aim to motivate the team. Professional fans have greatest impact by showing increasing support for the club outside match day, even sacrificing time and money to contribute towards the running of different organisations within the fan community. Fans are less attached to the team, while supporters display high levels of devotion.

\section{Figure 1 about here}

In previous research, the terms fan and supporter were often used interchangeably, so an aim of this research was to evaluate any distinctions between them during match day and in other settings and contexts. The patterns and strength of relationships between fans were investigated in order to help understand the factors enabling progression from one classification to the next. Respondents were asked to plot their past, present and potential future positions on the Spectrum and comment on the categories with which they identified. A further technique used was to investigate defining moments which had increased an individual's attachment to a club (Funk and James 2001). The research also investigated fans' accounts of the impact of social processes and experiences, notions of self and internal motivations on their behaviour, the impact of family and friends and any wider network influences.

\section{Findings:}


In providing background context, the Commercial and Communications Director explained that the club's brand is built on a strong community platform. There are 9,000 season ticket holders (male 70:30 female) and an average of 2,500 walk up fans per game. The club operates a customer relationship management (CRM) system with details of 70,000 individuals held on its database. Sources such as the club website, the Scottish Premier league official website, the BBC Football website, fan forums, match day programmes, current Scottish football news in the media, Morrow (2003) and the knowledge acquired by one of the researchers as a long term supporter of the club were also used to provide background information for research. Although the club acts as a focal point for the community, this could be improved. Relationships with the media and communications with fans could also be enhanced. There are also problems with the quality of Scottish football generally which leads to uncertainty about club specific income generation. The format of the Scottish league system may be redeveloped and each club will have a role to play in this reorganisation. Potential threats include the growing impact of football on television, the internet and mobile phones which affect actual match attendance. The uncompetitive nature of the league through dominance by the same teams each season results in an uneven spread of income.

\section{Emergence of alternative typology:}

Understanding loyalty requires depth investigation of the psychological processes involved (Mahoney et al 2000). Loyal supporters have been shown to evolve through experiences and socialisation. Demographic measurements such as attendance simply cannot measure this to any meaningful extent. It was found that support for the club was a process of attachment to the team and to others through social integration. Therefore respondents could not be placed on a single linear spectrum alone. They struggled to assign themselves to the categories suggested in Figure 1, with a sense that these groups being too narrowly defined. Some 
argued there was little difference between the Devoted and $12^{\text {th }}$ Man groups. Furthermore, although some fans highlighted constraints in their personal lives which prevented them from attending matches, they still remained devoted to their team. This required a distinction to be made between traditional and non traditional forms of support. A supporter could stop attending for a short period, yet take out a subscription to the club's television channel. Therefore, a more flexible framework was required to illustrate this. Beginning with early influences through family, many distinctions were made which led to the identification of four groups: Casual Followers, Fans, Social Devotees and Committed Supporters. So, comparison of the findings with the initial fan community supporter spectrum (Figure 1) resulted in an adjustment and subsequent construction of the Supporter Matrix (Figure 2) which accounts for the four fan groups associated with Hibernian FC.

\section{Development of the Supporter Matrix :}

The categories identified in the research are presented in the supporter matrix (Figure 2). It should be noted that divisions within the matrix are not mutually exclusive and that individuals can move within it and even exist on the borders e.g. develop into fully fledged fans or stay as, or revert to being followers. The comparison of our categorisations with Giulianotti and others has identified any overlaps and distinctions are clear. The matrix highlights the difference between a fan and supporter. Across the literature, the term 'fan' is used in almost every source consulted. Therefore it would be impractical to carry out research which does not acknowledge this term. By developing the matrix, it is hoped that future research will pay more attention to this distinction. The $\mathrm{x}$ and $\mathrm{y}$ axis of attachment to team and social integration are the main drivers of support. With respect to 'attachment to the team' it should be recognised that the team evolves and changes each. In 2002 Hibs took 25,000 fans to a cup final when their average attendance was around 12,000 and in 2007 they 
had 30,000 fans in a cup final when their average attendance was again 10-12,000. In 2004/05 Hibs saw average attendances increase by 2000 when Tony Mowbray was manager and they finished third in the league. This indicates that Hibs have fans who are not committed to going every week but who will become attached to the team depending on performance. Social Devotees are driven by fellow fans. A number stated that they would cease attending matches, or give up their season ticket if their friends stopped going, irrespective of how the team was doing. Here, social integration is a bigger driver for support than attachment to the team. Also, professionalism suggests specialism and payment and those interviewed disliked the term and disagreed with the concept. The research found that a supporter is the pinnacle of support and each does their best to support the team in any way they can. The matrix should also be viewed as dynamic so that any emerging categorisations can be incorporated. Individuals can be plotted along the diagonal line. The two stars representing specific individuals are located in different categories but the degree of differentiation is subtle in terms of overall support and attachment to the club. One is more driven through social experiences and consumption through non-traditional means and the other is more driven by the team and its success.

\section{Figure 2 about here}

The spectrum was originally formulated from an understanding of prior research and then used as the initial research instrument. The move away from the spectrum to the matrix can be explained by feedback received from respondents on the usefulness of the spectrum and rethinking by the researchers on how to conceptualise a more appropriate understanding of the club/fan relationship. Figure 3 details the characterstics of the four components of the matrix, reflecting the findings of the research. It also builds on and contrasts with previous work in the area in developing a detailed understanding of support, loyalty and social integration at a particular football club. An examination of the characteristics indicates that it 
is possible for social devotees to acquire over time the attributes of other members of the matrix, and so on, suggesting a forward progression. It is also possible for the more loyal fan to display lower levels of affinity if the individual has experienced changes in personal circumstances; for example a committed supporter may have to relocate because of a change in employment.

\section{Figure 3 about here}

\section{Qualitative fan interviews:}

The qualitative fan interview data relate not only to individual, subjective, phenomenological experiences but also contribute to wider social implications where groups of fans who share similar experiences then go on to form social groupings (Stirrat 1984; Donnelly and Young 1988; King 1997; Giulianotti 1999; Crawford 2003; Giulianotti 2005). The following discussion of the findings centres on the four types of fans identified from the research. Supporters attend matches regularly, display loyalty, have close relationships with each other over time and actively become involved in forming supporter organisations. The Fanatic or Fan has a more passive relationship with others associated with the team, and this relationship is dependent on team performance. The Social Devotee is motivated by the social experience and sense of belonging surrounding their support for the team. Followers do not attend matches regularly and utilise electronic media and other sources to keep up to date with team statistics.

\section{Committed Supporters:}

Immersion by one of the researchers within the central body of the club's following revealed relationships amongst more avid supporters to be very dense (Rowly 1997; Sparrowe et al. 2001). Being a supporter of the club was very much a lived experience, where the relationship with the club and with each other resembles a close knit family: 
"Even if I am looking for a painter or mechanic, I would find ones who are Hibs supporters, this might sound pedantic but I mean you feel friends never let you down and I treat Hibs supporters as friends" (Frank).

Just before kick off, fans sung the unofficial club anthem while holding their scarves aloft. This procedure is very much ceremonial (Derbaix and Decrop 2011). It is a vehicle of communication amongst the support that they are present that day, representing the local community and displaying the colours of the team. Supporters talked about the emotive consequences of the ritual, distinguishing themselves from other fans (Fiske 1992; Cova and Pace 2006):

"When [the club anthem] comes on, you know you're a true supporter when the hairs on the back of your neck stand up, other people who aren't true supporters will never understand how it feels" (Alex).

Knowledge of how to consume can set categories of fans apart (Dionsio et al. 2008). If attending the match is a ceremony, then the Hibernian FC stadium is a place of worship (Durkheim 1964; Belk et al. 1989). Supporters know all the nooks and crannies of the ground, reflected in their habitual routines:

"We park in the same street, walk down the same road, buy our programme from the same guy on Albion Road and always enter via turnstile 28, even if there's a queue and turnstile 27 is free, we wait and go in turnstile 28" (David).

Supporters also confirmed their closer connection with the team by calling players by their first name. Shouts of encouragement to their leading goal scorer were also heard during games. Keen supporters were closer to the club than other fans, confirming that supporters may adopt mannerisms which reflect the group they belong to (Donnelly and Young 1988).

An additional way to distinguish supporters from fans is the long term approach they take, where actions are taken with the club's best interest at heart. Figure 1 terms these fans Professional Supporters. Although professional suggests payment, those involved in supporter organisations make no money. The supporter trust, for example, is a fan led 
initiative which relies on help from the club for use of space. A strong connection to the club and relationship between fans enable better communication and increased support. As an illustration, Tom stated his reasons for being curator of the trust:

Well I wasn't good enough to be a player, or intelligent enough to be a director but I want to support the club in the best way I can, I feel proud being part of such an organisation.

Tom also explained he had written a book about the club's famous forward line, despite this being before his era. The motivation came from the fear of younger generations forgetting the past, typical of the attitude of those supporters at the end of the scale. They were very keen to lead and support the club, fellow supporters and fans in whatever way possible. In similar vein, Matty began another fan led initiative aimed at persuading fans who used to go to games to return once more. Supporters of this type held a long term view and were more rational and understanding in their views, particularly when faced with adversity. Alex admitted that, through supporters' organisations and connections with other fans, he was privy to more information which influenced his opinion. Supporter Frank echoed similar sentiments:

I can remember hundreds of people we have sold and think why this time? I would never be critical in the media about it, I would rather go direct to the chairman and tell them I disagree. Yes I'm in a different position as I know these people and get in to see them but I did start off as a normal supporter and I have had my volatile moments in different places but the club always comes first and I would never do anything to embarrass the club.

This category can be termed Committed Supporters. They go beyond all other categories of fans through their regular attendance, loyalty and the formation of many supporters' organisations. This group exhibit density through close relationships, unity through the bad times and a long term approach, reflective of the living journey they endure with their team. Committed supporters exhibit high levels of social integration in their 'family', shaped by their long term focus, heightened communication levels, their sense of unity in representing 
the team and the community as a lived experience. As a result, they are the most committed type of fan in that, once they reach this stage a virtuous circle effect applies. They become involved in more forms of social integration than other types of fan, with continual social affirmation of their identity, leading to even stronger social integration.

\section{The fan:}

The defining experience when fans knew they were going to become devoted to the club was analysed (Funk and James 2001). For many this occurred when they went to watch the team for the very first time:

"I remember my first game so vividly, being so young yet feeling such strong emotions that day when ... scored was really something. As soon as I got home I was at my dad to take me back and buy me the strip so I could try and be like my heroes that day" (Dave).

This form of support was very apparent amongst younger fans in particular. Before games, large groups gathered around the tunnel area, waving autograph books and camera phones in the direction of the players as they passed by. They embark on a quest for knowledge and become fanatical about the team (Redden and Steiner 2000):

"When the teleprinter on the TV typed up [the result], I burst into tears. My dad had told me this was the greatest team in the world and I believed everything he said, I couldn't understand it" (Thomas).

Another fan became devoted when as a 7 year old he watched the team lose a cup final:

"I could mention times when we beat Barcelona, but I think I was most devoted after the ...game, things were so bad that day. I thought I wanted to be a part of this" (Frank).

All fans who identified a defining moment singled out a game which was memorable for victory or defeat. It was clear that these fans firstly became attached to the club in the absence of any social experiences. When talking about their first game, an array of strong emotions were listed such as excitement (Brian), being overawed (Carrol), apprehension (Matty) and 
being overwhelmed (Ian) which made a lasting impression. These findings support Funk and James (2001) where a connection crystallises through experiences which are heightened if the fan has prior knowledge of the phenomenon. This evidence results in the identification of the Fanatic or Fan. Through their lived experiences they are more active than Followers (Van Mannen 1990; Reid et al. 2005). Fans have a more latent relationship with other supporters, and their closer connection with the team was confirmed in an investigation of attendances. When the team does well, fans are more inclined to attend. In 2007 the club had 30,000 supporters in the cup final, yet their average home attendance for the year was 14,448. Fans have a certain level of interest but more spurious loyalty (Dick and Basu 1994; Mahoney et a. 2000; Bauer et al. 2008).

Club supporters talked of the feeling of pride, despite periods of poor performance by the team (King 1997; Decropt and Derbaix 2010). The most pertinent example was when the city rivals' chairman attempted a takeover of the club. One supporter talked of the prevailing unity against this move:

"The rally of the troops was unbelievable. There was a thousand people trying to get into the ... club that day, everyone wanted somewhere to go" (Jim).

Another supporter took a holiday from work and bought $£ 2000$ of shares to help save the club, although as he puts it:

"The shares weren't worth the paper they were written on, but at least [the rival club chairman] didn't get them" (Thomas).

Supporters are proud to be there for the club when they need it most. Tam, for example, admitted to not being a regular attendee but having a level of devotion where he supported the club, particularly during periods where it was threatened with relegation. The close attachment felt by fans for their team is reflected in their moods mirroring the success or 
failure of their team (Cramer et al. 1986; Hirt et al. 1992). Their sense of social integration is still in a state of development, with many in this category being young fans.

\section{Social devotee:}

Social integration requires the effort to include oneself in a particular social group (Pons et al. (2006). As fans begin to gain more independence in their lives as they grow older, they utilise their experiences and knowledge to form circles of friend which, if threatened, could affect their support:

"This year we have been poor on the pitch, it's been all about the social aspect to keep us going, I like to go and see my mates, If this social side was to stop I could see my fan ship threatened, my mates keep me going through the bad times"(Daryl).

"It's more of a social thing going to the game, for example tomorrow we are at ...., we will get there early, have a meal, watch the game and then travel back and go out for a few drinks with friends, that's what makes the day" (Jim).

This is evident when walking to the ground on match day as a sea of coloured scarves converges from the adjoining streets when supporters filter from their preferred bar to the stadium. This behaviour lead to the identification of Social Devotees who place significant importance upon the social experience through which they can channel their support for the team (Fairley 2003). They have a yearning for social recognition (Crawford 2003) and may set out on a quest for belonging. This group was found to have constraints which may limit their attendance occasionally, but they do have many other characteristics of support. Jackie, who does not attend games because of her health, described herself as "more a fan of the club's fans," and has given up her time to get involved in the administration of the Supporters Club:

"It brings fans together and is a focal point for them to gather socially...It's like a family. There is always someone looking out for you and for me it's a better place to enjoy games" (Jackie). 
Social devotees support the team both through traditional ways such as match attendance and in non traditional ways such as internet forums which can also provide a close-knit virtual community (Kozinets 1999; Bagozzi and Dholakia 2002):

"The togetherness comes through even on [the club website]. I am there talking to fans 24/7 and I think there's a real community feel out there" (Matty).

Thomas suggests that when in need of club related information, his trump card would be to contact a fellow supporter, stressing the power of relationships with other supporters. Another indicates the impact of his social group:

"95\% of my friends, excluding family, are [club] supporters. When I am working I interact with ...supporters even on my tea break" (Frank).

They are also proud to represent their team in the wider community outside of match day:

"When [the team] were on a run of 22 games without winning against [their rivals]..., if we got beat I was always one of those people who still went out on a Monday morning with a [club] top or scarf on" (Frank).

The club scarf serves as a tool for communicating values (Dionsio 2008). For social devotees, knowledge and experience through following the club permits interaction with wider society:

Football provides great debate on Monday mornings; it's a feel good factor talking with fellow supporters about how well the team played. Added to that I always like to remind the [rival supporters] how to do it properly (Tam).

This body of supporters forms relationships with others around them. Their attendance at games can be limited but they make use of the internet and other media to engage with each other socially. This differs from fans who may be constrained by factors such as lack of time or money preventing their attendance. Their social integration is very much dependent on how they construct and share their social experience. Their levels of integration vary due to constraints on attendance but they do seek recognition for their support.

\section{Casual Followers:}


Clare is content to go to the occasional game but she mainly follows the club through the media. This behaviour is typical of the Casual Follower. They are defined as those who do not attend regularly, and choose instead to keep abreast of results and information from a distance:

"I don't attend much, but downloaded an app for my phone so I can keep updated with the scores." (Clare)

Followers lack knowledge and experience compared to their more devoted counterparts, forming only a loose relationship with other fans due to their lack of connections. This finding is consistent with Mahoney et al (2000) in that less committed followers forget the experience once it is over. Levels of social integration are less than those in other categories, There is still a 'felt' connection with the club, but physical interaction can be replaced by a preference for virtual relationships.

\section{Family and Community Influences:}

In addition to the above typology influences a number of fans attributed development of their support to their family. For many, support for the club stretched back generations, demonstrating a strong historical connection (Bradley 1998; Burdsey and Chappell 2001; Kelly 2007):

"I have family links right to 1875 and the ... Young Mens Society who formed the club, right through every generation we have been ... supporters, no one with my family name can support anyone else"(Frank).

The father and son bond is well established in the sports marketing literature (Kolbe and James 2000; de Groot and Robinson 2008; Jeanes and Magee 2011) but it is evident that many go beyond simply supporting the team their father did, with a sense of belonging being central (Donnelly and Young 1988; Crawford 2003): 
"I remember my dad telling me I owed my very existence to the club as he had taken a day off work to go and watch them only to be fired for doing so. Through his new job he met my mum"(Thomas).

For many the club is deeply embedded within the family, so that younger members can progress over time to develop their support. At the matches attended by the researcher, there was a real sense of a family atmosphere. The half time entertainment included families contesting a penalty shoot out, with goals often greeted by a father picking his son up in the air to celebrate, enabling him to observe the crowd reaction. The stadium also has a designated family section with special ticket deals. Strong community and family influences were reinforced (Melnick 1993; Carbaugh 1996; Bale 2000; Pons et al. 2006):

"The [family] area played a big part...I think supporting your local team is an important trait in football, it unites families and the wider community" (Brian).

Two important implications arise from these findings. Firstly the development of new fans is facilitated by existing supporters, especially through community and family influences. Secondly there needs to be a desire from fans to progress their own support. One thirteen year old supporter, Alex, described a defining moment when he knew he loved Hibs was when he went on a bus trip without his parents to see the team play in Europe. He knew it was the wrong thing to do from this parents' perspective, but it was also the right thing to do from his own perspective as a fan.

\section{Discussion:}

The identification of different fan orientations in these results can be compared to those developed by Giulianotti (2002) where collective behavioural forms are constructed via team and fellow supporter connections. His flaneur has no particular connection with a specific club but expresses a desire to attend and be seen at important events. The level of football attainment at the case stud y club does not really match the desire and conspicuous consumption expressed by the flaneur, although occasionally the club may reach important 
cup finals. Given the football structure in Scotland it is unlikely in the foreseeable future that the club will be a realistic challenger for winning the league and so is less likely to be an attractive proposition for the flaneur. However, it did reach the 2012 Scottish cup final and occasions such as this can attract such a supporter. The switching behaviour of the flaneur is not deemed to be a major influence on attendance and attachment in Scottish football consumption. Deeper cultural, historical and social factors discussed earlier in the paper have more important roles.

The Followers identified by the research do not attend regularly, consume at a distance and use technology to collect relevant information, although their interest dissipates over time. Their behaviour begins to approach that identified by Kozinets (1999) through their use of technology but the lower level of attachment means that they do not become part of a virtual community with its associated attributes. Interest in the use of technology by followers does, however, align to that of the flaneur but the reasons for its use are somewhat different. The fan identified in this research is impacted less by social experience and expresses lower levels of affinity with other supporters. Although individual lived experience is important, they are affected more by the impact of a particular memory or incident where emotional state is raised and endures over time. Their level of involvement is higher than the follower but less than the supporter. This compares to Giulianotti's fan who mirrors elements of consumer behaviour in other situations so that, if the experience is not matched by expectations, the individual concerned will seek out alternative consumption experiences. However, loyalty is maintained if the experience matches or exceeds expectations and the likelihood of consuming club products is enhanced. 
The attention of Giulianotti's fan is on the club or on a specific player but the depth of the relationship is looser than that expressed by supporters. The fan may wear club shirts in a show of solidarity with the team and this collective display can often be located internationaly throughout the fan base. In the case of fans at the case study club, it is more likely that these fans are more local, athough the club does attract some international attention. Giulianotti's follower connects with particular players, managers and others involved in the sport, even tracking player as they move from one club to another one. Displays of solidarity can vary from thick to thin, depending on the strength of the relationship. The degree of embeddedness between the follower and the club is less than that of the supporter and the relationship is more practical than symbolic. This differs to the social devotee found in this research where socialisation drives these individuals to become part of a group. Rates of social influence are high and socialisation can be carried out equally at match attendance and in social settings outside of the club.

There is certainly evidence of the working class supporter in this research, where traditional values and local community associations still exist. Although the club has a wider audience outside of the local area, most of its support is drawn from the community. The impact of this type of support is much greater than any flaneur influence. Elements of the traditonal fan identified by Critcher (1979) are also found in this research, aligning in part to the Supporter where strong attachment to the club, participation in club membership activities and regular match attendance are key attributes. The supporter can be viewed as representing the best interests of the club from a fan perspective through particpatory democracy (Taylor 1971). The topophilic relationship between supporter and the club's core spaces (Bale 1994) is also confirmed by this research. 
Much previous research refers to different categories of fans and this was incorporated in the original model, the fan community spectrum (Figure 1), to show a more fluid movement between fan types. As previously stated, one of the researchers has first hand knowledge of Hibernian which also helped to derive the groups. The club is particularly family orientedhence, the addition of the Hibs Kids category. The club also runs a $12^{\text {th }}$ man singing section so this was included too. However, when showing fans this model and asking them to identify where they saw themselves on the continuum, quite often the response was "well, I'm not a professional fan and I'm too old to sing so I'm not a $12^{\text {th }}$ man' so I would be devoted". It was apparent that categories were being selected through the process of elimination rather than because they actually represented actual characteristics. Respondents seemed to be interpreting the terms too literally; for example those who could recognise that they were probably in the 'professional supporter' category tended to dislike the term and that 'professional' suggests payment or a career and they didn't view themselves as better than others. Overall, our assessment of the spectrum was that it was being interpreted differently by different people. Therefore the construction of the matrix (Figure 2) endeavoured to introduce more accuracy. The horizontal axis indicates a fan's increasing attachment or loyalty to the team (Dick and Basu 1994; Bristow and Sebastian 2001; Tapp 2008; Bauer et al. 2008), and the vertical axis denotes the degree of social integration, reflecting the time supporters spend being socially active concerning their team (Giulianotti 1994; Bagozzi 2000; Pons et al. 2006). Initially, followers have limited social integration with fellow fans and are less inclined to attend matches. They do have a level of interest and look out for football results. Fans begin to get more attached to the team through attendance at matches and gain more experience and knowledge as a result. However, lack of social integration may affect their loyalty. Social Devotees increasingly look to 'fit in,' and attach themselves to a group. They are driven to attend by those around them, with going to a football match being 
perceived as a day out experience. It can also involve watching the game on television in the pub with friends. Supporters hold a strong attachment to their team and are highly socially active, with a very dense network. They are deemed very traditional since they channel their support through attending games. There was evidence of a high degree of dependancy from followers, fans and social devotees on supporters. They are instrumental in the development of new fans, and their status can have aspirational appeal to new fans. Supporters also rely on other fans in the matrix in order to increase the level of support generally. Support was found to be very much a fluid, lived experience (Van Mannen 1990; Nash 2000; Reid et al. 2005).

Following the data analysis, a definition of a supporter can be constructed:

A supporter is an individual who embarks upon lived experience, through developing a loyal attachment to the team and fellow supporters around them. This individual regularly attends games and offers finanical and any other form of support in the best way they can, particularly when the club needs it most. They are an integral part of the club, without whom the wider network of fans could not function. They express high levels of social integration and identity through their commitment to the football family (source: the authors).

Committed supporters exhibit high levels of social integration in their 'family', shaped by their long term focus, heightened communication levels, their sense of unity in representing the team and the community as a lived experience. As a result, they are the most committed type of fan in that, once they reach this stage a virtuous circle effect applies. They become involved in more forms of social integration than other types of fan, with continual social affirmation of their identity, leading to even stronger social integration.

\section{Conclusions and areas for future research:}

The Supporter Matrix makes the following contributions: (1) it extends descriptions of consumers of sport into more specific and distinctive niches; (2) it highlights the role of social integration as a means of consumption; (3) it demonstrates that football consumption is largely sequential, developed through experience, knowledge and social integration and (4) it 
provides a framework which identifies the main influences in football consumption. The original typology (Figure 1) which was tested was found to be innacurate, although it provided a useful starting point. The construction of the matrix containing casual followers, fans, social devotees and committed supporters simplified the typology and connected more clearly with the notion of a hierarchy of support. Future research should focus on the motivations of group consumption; for example, understanding what stimulates families, peers and supporter organisations. Another contribution concerns distinguishing supporters from all other groups of consumers associated with a football team. This then removes the difficulty of using fan and supporter terms interchangeably. The matrix can also provide the structure for testing with other football teams and different sports.

The research investigated whether support followed a sequential path. It was found that loyalty developed due to an accumulation of experience, knowledge and social integration. Fans have the potential to progress from casual follower to fan to social devotee to committed supporter. This could be tested further by carrying out longitudinal research through reinterviewing fans over a number of years. Furthermore, the impact of exposure to digital media on the speed of a fan's progression needs to be investigated in greater depth. Family and community were vital in starting the loyalty process. It emerged that, as relationships developed, social integration and unity amongst the support resulted in the most pride among supporters. The desire to win and the quest for success was evident but had little direct bearing on a supporter's loyalty or feelings of pride. Whilst there is in-depth knowledge on the factors impacting on team performance, the same depth must be mirrored in researching social processes in future studies. 
The Supporter Matrix extends the work of Funk and James' (2001) PCM model by adding a social dimension. Parralels exist whereby the PCM model denotes a fan's support progressing through extrinsic and then intrinsic influences (Bénabou and Tirole 2003). This is reflected in the data, which noted how external influences help to create a fan, before more personal relationships impact on progression. The Matrix can be compared to Crawford's (2003) conceptualisation of support following a career path, where principles of fluidity and the development of fans through processes are consistent. We continue to believe that supporters develop because they are keen and motivated, not because they are on a mission to become better than others. It should, however, be remembered that this is the context within the Hibernian supporters' community where those who invest greater support do aim to be top of the hierarchy. However a distinction can be made when Hibs play other teams such as Heart of Midlothian. Here the subculture and desire for distinction becomes apparent where Hibs supporters try to outsing and show they are a better club and better fans than their rivals. There is high motivation to be better than fans of opposing teams. Our research confirms Kolbe and James (2000) in emphasising that football support is far more than an impulse and that an individual is developed through significant others and social settings. Following this research, it is expected that the social aspect of supporting a club will continue to develop in importance (Decrop and Debraix 2010; Zagnoli and Radicchi 2010). Future research should also focus on casual followers so that greater distinctions can be made between the categories in the matrix. Football is a fast paced game and does not afford the opportunities to talk to fans in the setting of the stadium itself, a technique used in baseball by Holt (1995). This was an in-depth study of the situation surrounding one club. Whilst the case study approach has offered insights that a broader approach may overlook, it means that wider validity of the findings needs to be addressed in future studies across a number of clubs in a variety of divisions. The club has been identified as family oriented, operating within the community. 
For a larger club with global appeal, influences and patterns of support and loyalty may be different.

There are differences between the fans studied and fans of other types of clubs, including larger, more internationally oriented ones. Hibs do not have the same exit barriers as other clubs e.g. the stadium every week has around 8,000 empty seats. Therefore season ticket holders can give up their season ticket and know that any week when they want to attend, they can be guarenteed a seat, or even buy back their season ticket again. This can be contrasted with Liverpool, for example, where if someone gave up their season ticket it could be a very long wait until they acquired it again. With larger clubs, the form which social integration takes can be different, e.g through television exposure and globalisation effects. Sequential behaviour may not be the case either. This of course requires futher research. For Hibernian who exist in a tight community, playing in such an uncompetitive league has emphasised the social intergration aspect. Although the analysis carried out related to one club, there are clearly implications for all football clubs, as well as the wider sporting industry. The paper acknowledges the specific nature of the study and the potential differences found at larger clubs with a wider fan base and more international outlook. Efforts must be taken to understand the nature of the support and the levels of loyalty exhibited by the fan base. Treating all supporters as a homogenous mass is not an effective way to develop long term associations of loyalty. Acknowledging the role of the social world and the fact that fans are capable of moving within a dynamic supporter matrix can help to generate more effect longer term relationships between club and supporters. There are opportunities for club marketing managers to make use of increasingly sophisticated direct and database marketing techniques in the development of loyalty programmes, segmentation strategies and the heightening of lifetime values of fans associated with a club (Tapp 2008). 
So, for example the matrix could be used strategically by marketing managers to tailor specific loyalty programmes, offers and incentives for the four types. Committed supporters are the lifeblood of the club but may also be viewed as a mechanism for delivering higher levels of attachment in the less loyal casual follower. On-line documentary stories on the club website concerning the committed supporter relationship with the club could be used to stimulate higher levels of loyalty in the casual follower, while also facilitating the increased attachment of the fan and social devotee. These stories could also appear in match day programmes. If, however, the reltionship between club and each typology remain static, then opportunities for developing loyalty are lost. Another marketing strategy should focus on how to stimulate casual followers to become a fan or social devotee, with the expectation that they may well become committed supporters over time.

Another area for future research is the role which service dominant logic plays in supporting the idea of fan activity as a form of co-production (Lusch and Vargo 2006). Supporters, both physical and virtual, are now able to collaborate and co-create value with producers within their brand communities (Pongsakornrungslip and Schroeder 2011). This change in the sources of value creation have recently been viewed as a paradigm shift where consumers now create symbolic meaning and value through their consumption processes. This also further implies the possibility of progression or regression along a fan career path and would require longitudinal data collection in order to track behaviour changes over time. The strong community dynamic found at the club has impacted in particular ways which may not necessarily be seen at other clubs. Therefore, further research is required to access variations in this impact over time and at clubs with different levels of support, from the local through to the truly global level. The close club/community relationship identified in this research goes some way to counter the ritual of fan resistance found elsewhere; for example, the 
findings uncovered evidence of a willingness to buy up club shares to prevent a takeover. The club recognises its own weaknesses and is actively working with its fan base to improve relationships. It acknowledges the role of the community and therefore encourages the development of a benevolent connection between itself and its supporter organisations in working together to achieve common goals. This is evidence of collaboration and co-creation between club management and its core fan base. 


\section{References:}

Arnould, E., Price, L. and Zinkham, G. (2002). Consumers. New York, NY: McGraw-Hill.

Bagozzi, R.P. (2000). On the concept of intentional social action in consumer behavior. Journal of Consumer Research 27, 388-396.

Bagozzi, R.P. and Dholakia, U. (2002). Intentional social action in virtual communities. Journal of Interactive Marketing 16 (2), 2-21. doi: 10.1002/dir.10006,

Bale, J. (2000). The changing face of football stadiums and communities. Soccer and Society $l$ (1), 91-101. doi: 10.1080/14660970008721251

Bale, J. (1988). The place of 'place' in the cultural studies of sports. Progress in Human Geography 12, 507-524. doi: 10.1177/030913258801200403

Baudrillard, J. (1990). Seduction. London: Macmillan.

Bauer, H.H., Stockberger-Sauer, N.E. and Exler. S. (2008). Brand image and fan loyalty in professional team sport: a refined model and empirical assessment. Journal of Sport Management 22, 205-226.

Beech, J. And Chadwick, S. (2007). The marketing of sport. Harlow: Pearson Education Ltd.

Belk, R.W., Wallendorf, M. and Sherry, J.F. (1989). The sacred and the profane in consumer behavior: theodicy on the odyssey. Journal of Consumer Research 16, 1-38.

Bellah, R.N., Madsen, R., Sullivan, W.M., Swidler, A. and Tipton, S.M. (2004). Habits of the heart: individualism and commitment in American life. Berkeley: University of California Press.

Berkman, L.F., Glass, T., Brissette, I. and Seeman, T.E. (2000). From social integration to health: Durkheim in the new millenium. Social Science and Medicine 51 (6), 843-857. doi: 10.1016/S0277-9536(00)00065-4

Benabou, R. and Tirole, J. (2003). Intrinsic and extrinsic motivation. Review of Economic Studies 70, 489-520. doi: 10.1111/1467-937X.00253

Benjamin, W. (1999). The arcades project, R. Tiedermann (Ed.), translated by H. Eiland and K. McLaughlin. Cambridge, MA: Harvard University Press

Boyatzis, R.E. (1998). Transforming qualitative information: Thematic analysis and code development. London: Sage.

Boyle, R. and Haynes, R. (2000). Sport, the media and popular culture. Harlow: Pearson Education Ltd..

Bradley, J.M. (1998). Sport and the contestation of cultural and ethnic identities in Scottish society. Immigrants and Minorities 17 (1), 127-150. doi: 10.1080/02619288.1998.9974932 
Bristow, D. and Sebastian, R. (2001). Holy cow! Wait 'til next year. A closer look at the brand loyalty of Chicago Cubs baseball fans. Journal of Consumer Marketing, 18(3), 256275. doi: 10.1108/07363760110392976

Bryman, A. (2008). Social research methods. Oxford: Oxford University Press.

Burdsey, D. and Chappell, R. (2001). 'And if you know your history...' An examination of the formation of football clubs in Scotland and their role in the construction of social identity. The Sports Historian 21 (1), 94-106. doi: 10.1080/17460260109443378

Carbaugh, D.A. (1996). Situating selves: the communication of social identities in American scenes. Albany, NY: State University of New York Press.

Clarke, I. (1978). Football and working class fans. In R. Ingham, S. Hall, I. Clarke, P. Mann and J. Donavan (Eds.), Football hooliganism: the wider context. London: Interaction Imprint.

Clowes, J. and Tapp, A. (1999). Market segmentation in football clubs: an empirical investigation. Proceedings of European Association for Sport Management Conference, Thessaloniki, EASM.

Cova, B. (2006). Brand community of convenience products: new forms of customer empowerment - the case my Nuttella The Community. European Journal of Marketing 40 (9/10), 1087-1105. doi: 10.1108/03090560610681023

Cova, B. (1997). Community and consumption: towards a definition of the linking value of products or services. European Journal of Marketing 31 (3/4), 297-316. doi: $10.1108 / 03090569710162380$

Crawford, G. (2003). The career of the sport supporter: the case of Manchester Storm. Sociology, 37(2), 219-237. doi: 10.1177/0038038503037002001

Crawford, G. (2004). Consuming sport: fans, sport and culture. London: Routledge.

Critcher, C. (1979). Football since the war. In J. Clarke, C. Critcher and R. Johnson (Eds.), Working class culture: studies in history and theory. London: Hutchinson.

Decrop, A. and Derbaix, C. (2010). Pride in contemporary sport: a marketing perspective. Journal of the Academy Marketing Science, 38, 586-603. doi: 10.1007/s11747-009-0167-8

De Groot, M. and Robinson, T. (2008). Sport fan attachment and the psychological continuum model: a case study of an Australian football league fan. Leisure, 32 (1), 117-138. doi: 10.1080/14927713.2008.9651402

Deloitte (2009). Premier league clubs' revenues exceed $£ 2$ billion for the first time in 2009/10, despite the economic downturn, downloaded at http://www.deloitte.com/view/en_GB/uk/industries/sportsbusinessgroup/sports/football/annualreview-of-football-finance-2011/6b5666645ae60310VgnVCM2000001b56f00aRCRD.htm

Denzin, N. (1979). The research act, $2^{\text {nd }}$ edition. London: McGraw-Hill. 
Derbaix, C. and Decrop, A. (2011). Colours and scarves: an ethnographic account of football fans and their paraphernalia. Leisure Studies 30 (3), 271-291. doi: $10.1080 / 02614367.2010 .527356$

Derbaix, C., Decrop, A. and Cabossart, O. (2002). Colours and scarves: the symbolic consumption of material possessions by soccer fans. Advances in Consumer Research, 29, 511-518.

Dick, A. S. and Basu, K. (1994). Customer loyalty: toward an integrated conceptual framework. Journal of the Academy of Marketing Science. 22, 99-113. doi: $10.1177 / 0092070394222001$

Dionsio, P., Leal, C. and Moutinho, L. (2008). Fandom affiliation and tribal behaviour: a sports marketing application. Qualitative Market Research: An International Journal, 11(1), 17-39. doi: 10.1108/13522750810845531

Donnelly, P and Young, K. (1988). The construction and confirmation of identity in sport subcultures. Sociology of Sport,.5(3), 223-240.

Dunning, E. (1986). Sport as a male preserve: notes on the social sources of masculine identity and its transformations. Theory, Culture and Society 3, 79-90. doi: $10.1177 / 0263276486003001007$

Durkheim, E. (1964). The elementary forms of the religious life. London: Allen and Unwin.

Eisenhardt, K.M. (1989). Building theories from case study research. Academy of Management Review, 14 (4), 532-550. doi: 10.5465/AMR.1989.4308385

Euchner, C.C. (1993). Playing the field: why sports teams move and cities fight to keep them. Baltimore: John Hopkins University Press.

Fairley, S. (2003). In search of relived social experience: group-based nostalgia sport tourism. Journal of Sport Management 17 (3), 284-304.

Ferrand, A. and Pages, M. (1996). Football supporter involvement: explaining football match loyalty. European Journal for Sport Management, 3(1), 7-20.

Fiske, J. (1992). The cultural economy of fandom. In L. Lewis (Ed.), The adoring audience. London: Routledge.

Foster, W.M. and Hyatt, C.G. (2008). Inventing team tradition: a conceptual model for the strategic development of fan nations. European Sport Management Quarterly, 8 (3), 265-287. doi: $10.1080 / 16184740802224183$

Funk, D.C. and Brunn, T.J. (2007). The role of socio-psychological and culture-education motives in marketing international sport tourism: a cross cultural perspective. Tourism Management 28, 806-819. doi: 10.1016/j.tourman.2006.05.011

Funk, D.C. and James, J. (2006). Consumer loyalty: the meaning of attachment in the development of sport team allegiance. Journal of Sport Management, 20, 189-217. 
Funk, D.C. and James, J. (2001). The psychological continuum model: a conceptual framework for understanding an individual's psychological connection. Sport Management Review, 4, 119-150. doi: 10.1016/S1441-3523(01)70072-1

Funk, D.C., Ridinger, L.L. and Moorman, A.M. (2004). Exploring the origins of involvement: understanding the relationship between consumer motives and involvement with professional sport teams. Leisure Sciences 26 (26), 35-61. doi: $10.1080 / 01490400490272440$

Giulianotti, R. (2005). The sociability of sport: Scotland football supporters as interpreted through the sociology of George Simmel. International Review for the Sociology of Sport, 40 (3), 289-306. doi: 10.1177/1012690205060095

Giulianotti, R. (2002). Supporters, followers, fans and flaneurs. A taxonomy of spectator identities in football. Journal of Sport and Social Issues, 26 (1), 25-46. doi: $10.1177 / 0193723502261003$

Giulianotti, R. (1999). Football: a sociology of the global game. Cambridge: Polity.

Giulianotti, R. (1994). Social identity and public order: political and academic discourses on football violence. In R. Giulianotti et al. (Eds.), Football, violence and social identity. London: Routledge.

Gonzalez, B.M. (2005). Topophilia and topophobia. The home as an evocative place of contradictory emotions. Space and Culture 8 (2), 193-213. doi: 10.1177/1206331204273984

Gruen, T.W., Osmonbekov, T. and Czaplewski, A.J. (2005). How e-communities extend the concept of exchange in marketing: an application of the motivation, opportunity, ability (MOA) theory. Marketing Theory 5 (1), 33-49. doi: 10.1177/1470593105049600

Gruneau, R.S. and Whitson, D. (1993). Hockey night in Canada: sport, identities and cultural politics. Toronto: Garamond Press.

Hall, S. and Jefferson, T. (Eds.) (1976). Resistance through rituals. London: Harper-Collins.

Hirt, E. R., Zillmann, D., Erickson, G. A. and Kennedy, C. (1992). Costs and benefits of allegiance: changes in fan self- ascribed competencies after team victory versus defeat. Journal of Personality and Social Psychology, 63, 724-738.

Holt, D. (1995). How consumers consume: a typology of consumption practices. Journal of Consumer Research, 22, 1-16.

Holt, D. (1998). Does cultural capital structure American consumption? Journal of Consumer Research 25 (1), 1-26.

Hunt, K.A., Bristol, T. and Bashaw, E. (1999). A conceptual approach to classifying sports fans. Journal of Services Marketing, 13(6), 439, 452. doi: 10.1108/08876049910298720 
James, J.D. and Ross, S.D. (2004). Comparing sport consumer motivations across multiple sports. Sport Marketing Quarterly 13 (1), 17-25.

Jeanes, R. and Magee, J. (2011). Come on my son! Examining fathers, masculinity and fathering through football. Annals of Leisure Research 14 (2/3), 273-288. doi: $10.1080 / 11745398.2011 .616483$

Kelly, J. (2007). Hibernian football club: the forgotten Irish. Sport in Society 10 (3), 514-536. doi: 10.1080/17430430701333950

Kent, R.A. (2006). Marketing research: approaches, applications and research in Europe. London: Thomson Learning.

King, A. (1997). The lads: masculinity and the new consumption of football. Sociology, 31(2), 29-346. doi: 10.1177/0038038597031002008

Kolbe, R. H. and James, J. D. (2000). An identification and examination of influences that shape the creation of a professional team fan. International Journal of Sports Marketing and Sponsorship, 2 (1), 23-37.

Kozinets, R.V. (2001). Utopian enterprise: articulating the meanings of Star Trek's culture of consumption. Journal of Consumer Research, 29, 67-88.

Kozinets, R.V. (1999). E-tribalised marketing? The strategic implications of virtual communities of consumption. European Management Journal 17 (3), 252-264. doi: 10.1016/S0263-2373(99)00004-3

Lash, C. (1991). The true and only heaven: progress and its critics. New York: Norton.

Lewis, M. (2001). Franchise relocation and fan allegiance. Journal of Sport and Social Issues, 25 (1), 6-19. doi: 10.1177/0193723501251002

Lofland, J. and Lofland, L. (1984). Analysing social settings: a guide to qualitative observation and analysis. Belmont, CA: Wadsworth.

Lugton, A. (1995). The making of Hibernian. Edinburgh: J. Donald.

Lusch, R. F. and Vargo, S. L. (2006) Service Dominant Logic- Reactions, Reflections and Refinements. Marketing Theory. Vol 6, (3), pp281-288. doi: 10.1177/1470593106066781

Mackay, J.R. (1986). The Hibees: the story of Hibernian football club. Edinburgh: J. Donald.

Mahoney, D. F., Madrigal, R. and Howard, D. (2000). Using the psychological commitment to team (PCT) scale to segment sport consumers based on loyalty. Sport Marketing Quarterly, 9 (1), 15-25.

Marchand, R. (1985). Advertising: the American dream. Berkeley: University of California Press.

Mason, T. (1989). Sport in Britain. A social history, Cambridge: Cambridge University Press. 
McDonald, H., Kart, A.J. and Lock, D. (2010). Leveraging fans' global football allegiances to build domestic league support. Asia Pacific Journal of Marketing and Logistics 22 (1), 6789. doi: 10.1108/13555851011013164

McLuhan, M. (1964). Understanding media. London: Routledge.

MacVannan, A. (2011). We are Hibernian. Edinburgh: Luath Press.

Melnick, M.J. (1993). Searching for sociability in the stands: a theory of sports spectating. Journal of Sports Management, 7,44-0.

Morrow, S. (2003). The peoples game? Football finance and society. London: Palgrave Macmillan.

Morrow, S. (2006). Scottish football - it's a funny old business. Journal of Sports Economics 1, 7 (1), 90-95. doi: 10.1177/1527002505282867

Morrow, S. (2004). The financial crisis in Scottish football. Scottish Affairs 47.

Muniz, A. M. and O'Guinn, T. C. (2001). Brand community. Journal of Consumer Research, $27,412-432$.

Muniz, A.M. and Schau, H.J. (2005). Religiosity in the abandoned Apple Newton brand community. Journal of Consumer Research 31, 737-747.

Nash, R. (2000). Contestation in modern English football. International Review for the Sociology of Sport, 35(4), 439-452. doi: 10.1177/101269000035004002

Paton, M. Q. (1980). Qualitative evaluation methods. London: Sage.

Pongsakornrungsilp, S. and Schroeder, J. (2011). Understanding value co-creation in a coconsuming brand community. Marketing Theory 11(3), 303-324 doi $10.1177 / 1470593111408178$

Pons, F., Mourali, M. and Nyeck, S. (2006). Consumer orientation toward sporting events: scale development and validation. Journal of Service Research, 8(3), 276-287. doi: $10.1177 / 1094670505283931$

Pooley, J.C. (1978). The sports fan: a social psychology of misbehaviour. Capher Sociology of Sport Monographic Series: University of Calgary.

Pritchard, M.P. and Funk, D.C. (2010). The formation and effect of attitude importance in professional sport. European Journal of Marketing 44 (7/8), 1017-1036. doi: 10.1108/03090561011047508

Pritchard, M.P., Funk, D.C. and Alexandris, K. (2009). Barriers to repeat patronage: the impact of spectator constraints. European Journal of Marketing 43 (1/2), 169-187. doi: $10.1108 / 03090560910923283$ 
Quick, S. (2000). Contemporary sport consumers: some implications of linking fan typology with key spectator variables. Sport Marketing Quarterly, 9(3), 149-156.

Redden, J. and Steiner, C.J. (2000). Fanatical consumers: towards a framework for research. Journal of Consumer Marketing, 17(4),.322-337. doi: 10.1108/07363760010335349

Reid, K., Flowers, P., and Larkin, M. (2005). Exploring lived experience. Psychologist, 18 (1). 20-23.

Rheingold, H. (1993). The virtual community: homesteading on the electronic frontier. Reading, MA: Addison-Wesley.

Richardson, B. and Turley, D. (2006). Support your local team: resistance, subculture and the desire for distinction. Advances in Consumer Research 33, 175-180.

Ritson, M. and Dobscha, S. (1999). Marketing heretics: resistance is/is not futile. In E.J. Arnould and L. Scott (Eds.) Advances in Consumer Research 26, Provo, UT: Association for Consumer Research, 159.

Rowly, T.J. (1997). Moving beyond dyadic ties: a network theory of stakeholder influences. The Academy of Management Review, 22 (4), 997-910.

Sands, R. S. (2002). Sport ethnography. Washington: Library of Congress Cataloguing-inpublication Data.

Shilbury, D., Quick, S. and Westerbeek, H. (2003). Strategic sport marketing, Melbourne: Allen \& Unwin.

Sparrowe, R.T., Laden, R.C., Wayne, S.J. and Kramer, M.L. (2001). Social networks and the performance of individuals and groups. The Academy of Management Journal 44 (2), 316325.

Stewart, B., Smith, A.C.T. and Nicholson, M. (2003). Sport consumer typologies: a critical review. Sport Marketing Quarterly, 12(4): 206-216.

Stirrat, R.L. (1984). Sacred models. Man 19 (2), 199-215.

Stone, c. (2007). The role of football in everyday life. Soccer and Society 8 (2/3), 169-184. doi: 10.1080/14660970701224319

Tapp, A. (2008). Principles of Direct and Database Marketing: A Digital Orientation, Financial Times/ Pitman, Fourth Edition

Tapp, A. (2004). The loyalty of football fans - we'll support you evermore? Database Marketing and Customer Strategy Management, 11 (3), 203-215. doi: 10.1057/palgrave.dbm.3240221 
Tapp, A and Clowes, J. (2002). From 'carefree casuals' to 'professional wanderers' segmentation possibilities for football supporters. European Journal of Marketing, 36 (11/12), 1248-1269. doi:

Taylor, I. (1971). Football mad: a spec10.1108/03090560210445164ulative sociology of football hooliganism. In E. Dunning (Ed.), The sociology of sport: a selection of readings. London: Cass.

Taylor, J.A. (2004). Tribes, brands and the fate of consumer marketing. Consumer Insight Magazine. In P. Dionsio, C. Leal and L. Moutinho, (2008) Fandom affiliation and tribal behaviour: a sports marketing application. Qualitative Market Research: An International Journal, 11 (1), 17-39.

Taylor, S. J., \& Bogdan, R. (1984). Introduction to qualitative research methods: the search for meanings. New York: John Wiley \& Sons.

Thorne, S. and Bruner, G.C. (2006). An exploratory investigation of the characteristics of consumer fanaticism. Qualitative Market Research: An International Journal, 9(1), 51-72. doi: $10.1108 / 13522750610640558$

Thornton, S. (2002). Club cultures: music, media and subcultural capital. Oxford: Blackwells.

Thorpe, S. (2011). An exploratory investigation of the theorised levels of consumer fanaticism. Qualitative Market Research: An International Journal 14 (2), 160-173. doi: $10.1108 / 13522751111120675$

Tolson, A. (1977). The limits of masculinity. London: Tavistock.

Tuan, Y-F. (1974). Topophilia. Englewood Cliffs: Prentice-Hall.

Van Houtum, H. and Van Dam, F. (2002). Topophilia or topoporno? Patriotic place attachment in international football derbies. International Social Science Review, 3 (2), 231248.

Van Mannen, M. (1990). Researching lived experience: human science for an action sensitive pedagogy. London, Ontario: University of Western Ontario.

Walsh and Giulianotti (2001). This sporting mammon: a normative analysis of the commodification of sport. Journal of the Philosophy of Sport, 5 (2/3), 39-50. doi: 10.1080/00948705.2001.9714600

Wann, D. L. and Branscombe, N.R. (1993). Sports fans: measuring degree of identification with their team. International Journal of Sport Psychology, 24, 1-17.

Wann, D.L., Melnick, M.J., Russell, W. and Pease, D.G. (2001). Sports fans: the psychology and social impact of spectators. New York, NY: Routledge.

Willis, P. (1977). Learning to labour. Farnborough, Hants: Saxon House. 
Wright, T. (2010). The golden years: Hibernian in the days of the famous five. Derby: DB Publishing.

Yin, R. K. (2009). Case study research, design and methods. London: Sage.

Zagnoli, P. and Radicchi, E. (2010). The football-fan community as a determinant stakeholder in value co-creation. Sport in Society, 13 (10), 1532-1551. doi: $10.1080 / 17430437.2010 .520941$

FIGURE 1: COMMUNITY-FAN-SUPPORTER SPECTRUM

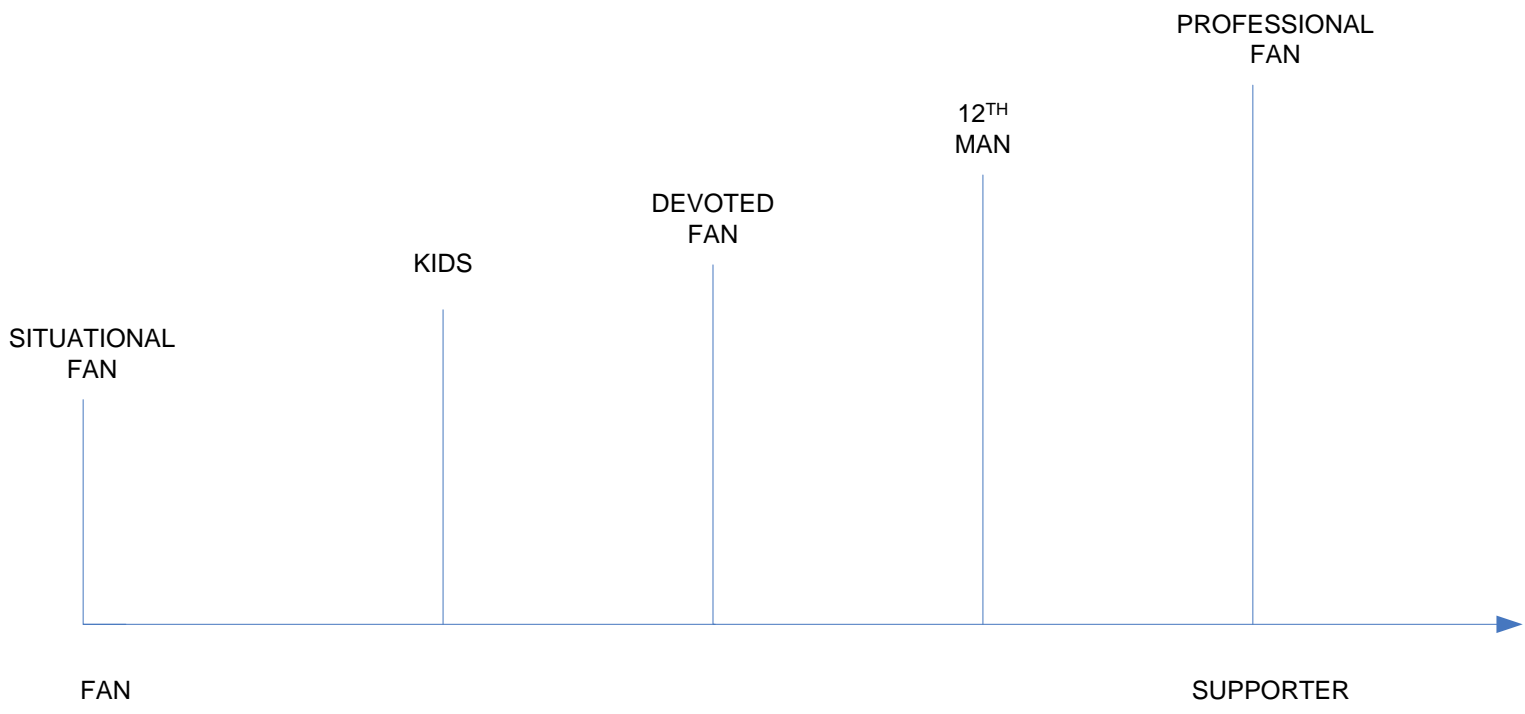

(Source: the authors) 


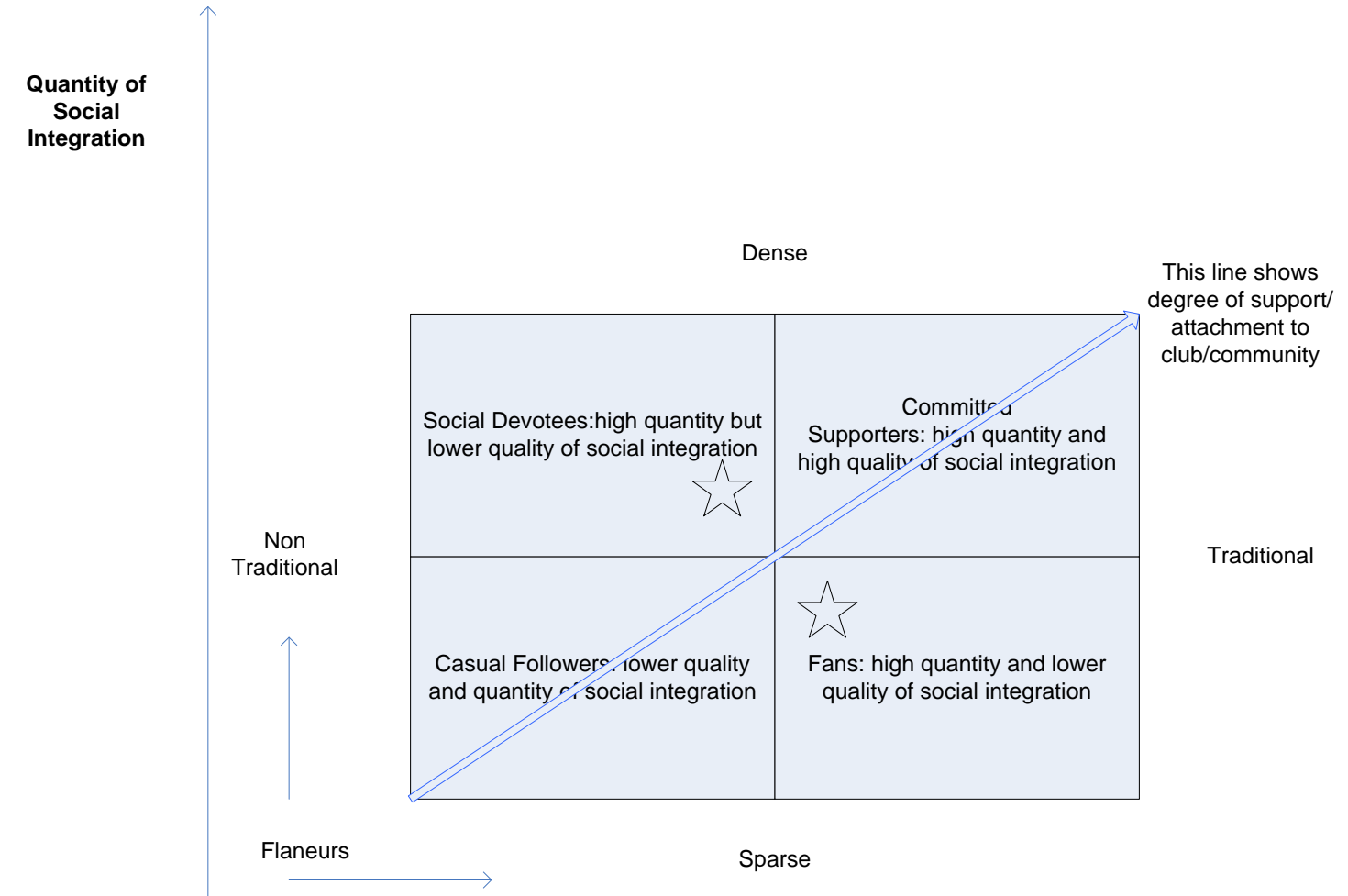

Quality of Social Integration: Attachment

to the team

Figure 2: Supporter Matrix (source: the authors) 
Figure 3: Supporter matrix characteristics (source: the authors)

\begin{tabular}{|c|c|}
\hline $\begin{array}{l}\text { Social Devotee: } \\
\text { Looks to fit in } \\
\text { Seeks group attachment within a community } \\
\text { Football as day out experience at stadium, } \\
\text { pub or other venue } \\
\text { Craves social recognition and belonging } \\
\text { Supports team through match attendance and } \\
\text { on-line forums } \\
\text { Lower chance of acquiring and displaying } \\
\text { subcultural capital attributes }\end{array}$ & $\begin{array}{l}\text { Committed Supporter: } \\
\text { Highly socially active } \\
\text { Dense network } \\
\text { Traditional match attendance } \\
\text { Followers, fans and social devotees depend } \\
\text { on supporter for inspiration and motivation } \\
\text { Catalyst behind creation of new fans } \\
\text { Relies on other groups to lend support } \\
\text { Support is lived experience involving } \\
\text { sacrifice, ritual, high levels of loyalty, } \\
\text { allegiance, fanaticism, religiosity and pride } \\
\text { Will actively use social media to heighten } \\
\text { their connection with the club and with other } \\
\text { supporters } \\
\text { Exhibit high levels of subcultural capital not } \\
\text { only through wearing of club shirts but also } \\
\text { through singing, chanting and feelings of } \\
\text { togetherness during match day and other } \\
\text { times of the week }\end{array}$ \\
\hline $\begin{array}{l}\text { Casual Follower: } \\
\text { Initial limited social integration } \\
\text { Less inclined to attend matches but interested } \\
\text { in the team and their performance } \\
\text { Lacks knowledge and experience } \\
\text { Loose connection with others } \\
\text { Less committed followers forget the } \\
\text { experience over time } \\
\text { Do not attend regularly } \\
\text { Consume at a distance } \\
\text { Use technology to collect information but do } \\
\text { not become part of virtual community } \\
\text { Exhibits some flaneur characteristics but has } \\
\text { different motives } \\
\text { No real possibility of exhibiting subcultural } \\
\text { capital characteristics }\end{array}$ & $\begin{array}{l}\text { Fan: } \\
\text { Displays attachment to the team through } \\
\text { match attendance and conveys a degree of } \\
\text { subcultural capital through wearing of team } \\
\text { shirts, scarves etc. } \\
\text { Gains experience of the team over time } \\
\text { Impacted less socially } \\
\text { Expresses lower level of affinity with others } \\
\text { Although individual lived experience is } \\
\text { important, affected more by specific } \\
\text { memories and incidents } \\
\text { Differs to Giulianotti's fan who switches } \\
\text { attention when dissatisfied by consumption } \\
\text { experience } \\
\text { May also use electronic media to follow the } \\
\text { team but level of intensity is less than the } \\
\text { committed supporter }\end{array}$ \\
\hline
\end{tabular}


